\title{
EFFICIENCY OF PRE-TREATMENT OF LEACHATE FROM MUNICIPAL WASTE DUMPS BY GASEOUS DESORPTION (STRIPPING) OF AMMONIA
}

\author{
Justyna Koc-Jurczyk' ${ }^{1}$ Łukasz Jurczyk', Kamil Olszówka' \\ 1 University of Rzeszow, Faculty of Biology and Agriculture, Department of Biological Basis of Agriculture and \\ Environmental Education, 1b Cwiklinskiej St., 35-601 Rzeszow, Poland, e-mail: jjurczyk@ur.edu.pl
}

Received: 2017.02.06

Accepted: 2017.04.05

Published: 2017.05.02

\begin{abstract}
The paper studies the efficiency of pre-treatment of landfill leachate by gaseous desorption of ammonia. The research was done on a municipal non-hazardous waste dump in Krosno (Sub-Carpathian Province, Poland). The pretreatment provided a favorable $\mathrm{BOD}_{5} / \mathrm{COD}$ ratio in leachate. Also concentrations of $16 \mathrm{PAHs}$ and heavy metals did not exceed the legal limits. However, gaseous desorption of ammonia was insufficiently efficient in recovering ammonia nitrogen from leachate.
\end{abstract}

Keywords: landfill leachate, gaseous desorption of ammonia, retardation of adverse environmental effect

\section{INTRODUCTION}

General availability of consumer goods in combination with benefits of democracy and freedom of speech have become a fundamental value to inhabitants of many regions of the world. This relates to excessively rapid changes in a form of wealth increment. The concept of economic growth adopted by economists and valid develops at an exponential rate, covering numerous technologies. This involves the following: limited living space for humans; immunity of man and other components of the biosphere on the increasing pace of environmental change; chemicalization of the environment producing pollution of air, waters and soils with dusts, toxins and wastes; and shrinking resources of biological diversity [Kostecka and Kostecki 2014]. The condition of approximately $2 / 3^{\text {rds }}$ of benefits from ecosystems being a basis for human life, is deteriorating; these ecosystems are considered as degraded or as functioning discordantly with the concept of sustainable development [Kostecka 2013]. Highly developed countries and the style and conditions of life that they enforce influence the aggravating state of human health. 'Retardation' is a phenomenon counteracting the deterioration of life quality of humans. It is a word of Latin origin (retardatio), it can be used on environmental plane, meaning phenomena that delay, inhibit, stop or slow down natural processes, broadly defined pace of technological development of man, phenomena in biosphere leading to loss of biodiversity, transformation of space and others [Kostecka 2010].

Improvement in human life quality relates to increased quantity of waste being produced. Both municipal and certain industrial wastes neutralized by storage can contain mixtures of various types of harmful substances. 'Useless' products removed to dump sites after use by households or industry are the source of these substances.

As a result of long dwelling in the dump's bed, they undergo partial degradation, the consequence of which is the appearance of a certain quantity of potentially harmful compounds in leachate. Composition of leachate is often similar to that of many other liquid waste types: dissolved organic matter or inorganic salts but also heavy metals and a wide range of organic compounds of xenobiotic nature [Slack et al. 2005].

Not all organic substances present in leachates are identified because of low concentration of analytical technique limitations. Concentration of organic compounds $\left(\mathrm{BOD}_{5}, \mathrm{COD}\right)$, mineral compounds (nitrate nitrogen (III) and (V), ammo- 
nia nitrogen, phosphorus) or content of metals are the main parameters used to describe composition of pollutants in leachates. According to Slack et al. [2005], more than 200 organic substances, including 35 ones generally considered harmful, were identified in leachates from municipal dumps. Consequently, the quantity of various types of substances found in underground water around waste dumps exceeded 1,000. This means that transformation and/or partial degradation of various types of harmful substances leads to release of intermediate products and can be a source of subsequent pollution of underground waters.

The chemical composition of a leachate depends on, among others, waste storage duration. Leachates from young municipal landfill dwelling in acid phase feature low $\mathrm{pH}$, medium concentration of ammonia nitrogen (500-2,000 mg. $\mathrm{dm}^{-3}$ ), high concentration of organic substances expressed as COD $\left(30,000-60,000 \mathrm{mg}^{-3} \mathrm{dm}^{-3}\right)$ and $\operatorname{BOD}\left(4,000-13,000 \mathrm{mg} \cdot \mathrm{dm}^{-3}\right)$. As a result, the $\mathrm{BOD} / \mathrm{COD}$ ratio ranges from 0.4 to 0.7 . In the methane phase, leachates contain mostly sparingly degradable organic substances, and $\mathrm{pH}$ increases to approx. 7. As the waste storage gets older, leachates grow rich in ammonia nitrogen $\left(3,000-5,000 \mathrm{mg}^{-3}\right)$ and poor in COD

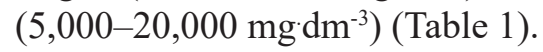

Pre-treating and removing leachate from municipal landfill poses a major technical problem. The solution prevailing in Poland and other EU states consists of transporting leachate in waste removal tank trucks to nearby sewage treatment plants or discharging it directly to sewers. However, treating leachate and other liquid waste together is not the optimal approach. High concentration of ammonia nitrogen in leachate has adverse effect on activated sludge, which puts at risk stability of operation of municipal treatment plants. The mixing of the two streams of liquid waste can lead to exceeding limits on the content of nitrogen compounds in treated waste or the content of heavy metals in sludge. There are many literature sources that propose physical and chemical methods for pre-treating leachate from municipal landfills [Kurniawan et al. 2006, Wiszniowski et al. 2006, Renou et al. 2008, Cotman and Gotvajn 2010]. Gaseous desorption is one of the most efficient method of recovering ammonia nitrogen. For the process to be efficient, it should be run at a $\mathrm{pH}$ of 10.5-12 [Bonmati and Flotats 2003]. The value of $\mathrm{pH}$ is critical for the occurrence of ammonia nitrogen in leachate: if $\mathrm{pH}$ is neutral, most ammonia has the form of the ammonium ion $\left(\mathrm{NH}_{4}^{+}\right)$while an increment in $\mathrm{pH}$ results in release of free ammonia $\left(\mathrm{NH}_{3}\right)$ that is much more toxic to aquatic organisms and microflora and that releases from water solution to atmosphere in gaseous form. Where $\mathrm{pH}$ is 11 or more, the process is very dynamic [Guo et al. 2010]. Because they are relatively simple in design and inexpensive in operation, systems for gaseous desorption of ammonia were installed in recent years in many facilities for which recovery of ammonia represented a major task. However, according to figures, the efficiency of this process can fail to meet the original assumptions.

The study aimed to evaluate efficiency of pretreatment leachate from municipal non-hazardous waste landfill in Krosno. Because leachate is discharged to the sewers after pre-treatment, the effluent has to comply with the Regulation by the Minister of Construction of 14/07/2006 on requirements for industrial effluent suppliers and for discharging effluents to sewers.

\section{MATERIALS AND METHODS}

The leachate concerned came from a municipal non-hazardous waste landfill situated in Krosno, operated since 1983, complying with the

Table 1. Composition of landfill leachate depending on time of landfill operation

\begin{tabular}{|c|c|c|c|}
\hline Parameter & Young & Intermediate & Stabilized \\
\hline Age (years) & $<5$ & $5-10$ & $>10$ \\
\hline $\mathrm{pH}$ & $<6.5$ & $6.5-7.5$ & $>7.5$ \\
\hline $\mathrm{COD}\left[\mathrm{mg}^{\left.-\mathrm{dm}^{-3}\right]}\right.$ & $>10,000$ & $4,000-10,000$ & $<4,000$ \\
\hline BOD/COD ratio & $0.5-1.0$ & $0.1-0.5$ & $<0.1$ \\
\hline Organic compounds & $80 \%$ (VFA) & $\begin{array}{l}5-30 \% \text { VFA + humic } \\
\text { and fulvic acids }\end{array}$ & humic and fulvic acids \\
\hline $\mathrm{N}-\mathrm{NH}_{4}{ }^{+}\left[\mathrm{mg} \cdot \mathrm{dm}^{-3}\right]$ & $<400$ & N.A. & $>400$ \\
\hline $\mathrm{TOC} / \mathrm{COD}$ & $<0.3$ & $0.3-0.5$ & $>0.5$ \\
\hline Heavy metals concentration [mg.dm ${ }^{-3}$ ] & low to medium & low & low \\
\hline
\end{tabular}


Regulation by the Minister of Environment of $26 / 02 / 2009$ on detailed requirements for location, construction, operation and closure of various waste dump types [Dz. U. 39, poz. 320].

The landfill has a leachate pre-treatment plant. The effluent is pumped from the landfill's drainage system to one of 3 aerated tanks, 2 of which act as reactors for gaseous desorption of ammonia and the $3^{\text {rd }}$ one serves as a storage tank. It was assumed that gaseous desorption of ammonia nitrogen at $\mathrm{pH}>11$ would efficiently eliminate the gas from leachate. This $\mathrm{pH}$ value is maintained by feeding lime milk to the reactors. Reacted leachate is pumped to a settling tank where $\mathrm{pH}$ is lowered to approx. 9.5 with concentrated sulfur acid. So pre-treated leachate is pumped to the municipal sewerage.

Raw leachate was sampled from the storage and aerating tank and pre-treated leachate was taken from the neutralization tank once every 3 months in years 2011-2013, in accordance with the sampling instructions contained in the PNISO 5667-10:1997 standard.

Physical and chemical analyses of leachate, including determination of organic substances (BOD 5 [PN-EN 1899-2:2002], COD [PN-ISO 6060:2006]), total organic carbon (TOC) [PN-EN 1484:1999], the total content of the standard 16 PAHs [PN-ISO 17993:2005], ammonia nitrogen [PN-ISO 5664:2002], total phosphorus [PN-EN 6878:2006], total chrome [PN-EN 1233:2,000P], heavy metals $\left(\mathrm{Pb}, \mathrm{Cd}, \mathrm{Cu}, \mathrm{Zn}, \mathrm{Cr}^{+6}, \mathrm{Hg}, \mathrm{Ni}\right)[\mathrm{PN}-$ ISO 8288:2002], $\mathrm{pH}$ [PN/90/C-04540.01] and electrolytic conductivity [PN-EN 27888:1999], were done by the Central Water and Effluent Testing Laboratory in Krosno and by the Waste Management Laboratory of the Rzeszow University.

\section{RESULTS AND DISCUSSION}

\section{Removal of organic substances from leachate}

Concentrations of organic substances in raw and pre-treated leachates were strongly dependent on season and varied between the years covered (Fig. 1). The values of COD in raw leachate ranged from 670 to $1,281 \mathrm{mg} \cdot \mathrm{dm}^{-3}$ and concentrations of easily degradable organic substances expressed as $\mathrm{BOD}_{5}$ varied within the $174-733 \mathrm{mg}$. $\mathrm{dm}^{-3}$ range. As a result, the $\mathrm{BOD}_{5} / \mathrm{COD}$ ratio for the leachates was $0.16-0.76$.
The pre-treatment of leachates lowered COD from $7 \%$ to $44 \%$ and BOD 5 from $4 \%$ to $75 \%$. Therefore, the $\mathrm{BOD}_{5} / \mathrm{COD}$ ratio dropped to $0.23-0.54$.

According to determination of TOC, raw leachate contained the largest concentration of organic substances expressed as carbon in the $2^{\text {nd }}$ quarter of $2011\left(480 \mathrm{mg}^{-3} \mathrm{dm}^{-3}\right)$ and the lowest one in the $1^{\text {st }}$ quarter of $2012\left(62.2 \mathrm{mg} \cdot \mathrm{dm}^{-3}\right)$. The efficiency of recovery of TOC by the pre-treatment ranged from $12 \%$ (quarter 4 . 2011) to $74 \%$ (quarter 4. 2012).

The side effect of recovering organic substances from leachate by gaseous desorption of ammonia at high $\mathrm{pH}$ is arguable. Based on a literature review, the efficiency of organic substance recovery can reach $27 \%$ for COD and $7 \%$ for $\mathrm{BOD}_{5}$ [Liu et al. 2015] or, according to Blauvelt [2009] - 27-42\%. Kurniawan et al. [2006] achieved a $21-47 \%$ COD removal efficiency for leachates from municipal waste dumps. Then, Yuan et al. [2016] claimed that processing leachates by gaseous desorption of ammonia would not have a significant effect on the concentration of COD. Also Calli et al. [2005] wrote that the stripping removed not more than $15 \%$ of COD. So, it seems that gaseous desorption of ammonia should not be used specifically for recovering sparingly degradable substances from leachates [Kurniawan et al., 2006].

\section{Removal of total polycyclic aromatic hydrocarbons (PAH)}

The concentration of all the 16 PAHs in raw leachate ranged from 0.19 to $1.6 \mu \mathrm{g} \cdot \mathrm{dm}^{-3}$ in 2011 (Fig. 2) and in the two following years the concentrations in both raw and pre-treated leachate did not exceed $0.1 \mu \mathrm{g} \cdot \mathrm{dm}^{-3}$. Based on the Regulation by the Minister of Construction of 14/07/2006 on requirements for industrial effluent suppliers and for discharging effluents to sewers [Dz.U. 2006, nr135, poz. 964], setting limits for PAHs (among several other limits for industrial effluents), the official limit of $0.2 \mathrm{mg}^{-3 m^{-3}}\left(200 \mu \mathrm{g} \cdot \mathrm{dm}^{-3}\right)$ was not exceeded during the period under review.

Matejczyk et al. [2011] investigated into the contents of leachates in Poland. The authors analyzed leachates from 22 dump sites operated for from 1 to 25 years. Their results for the 16 PAHs in all their samples ranged from 0.057 to as much as $77.2 \mu \mathrm{g} \cdot \mathrm{dm}^{-3}$. For the municipal waste dump in Wysieka near Bartoszyce the figure was 2.7 $\mu \mathrm{g} \cdot \mathrm{dm}^{-3}$ [Koc-Jurczyk 2014]. 


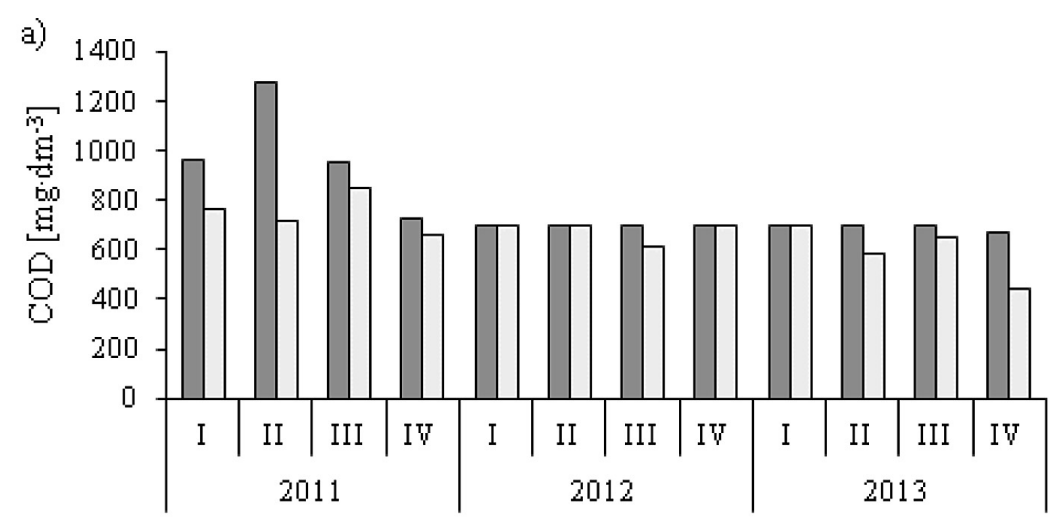

口rawleachate $\quad$ ppre-treatment leachate



$\square$ rawleachate $\square$ pre-treatment leachate

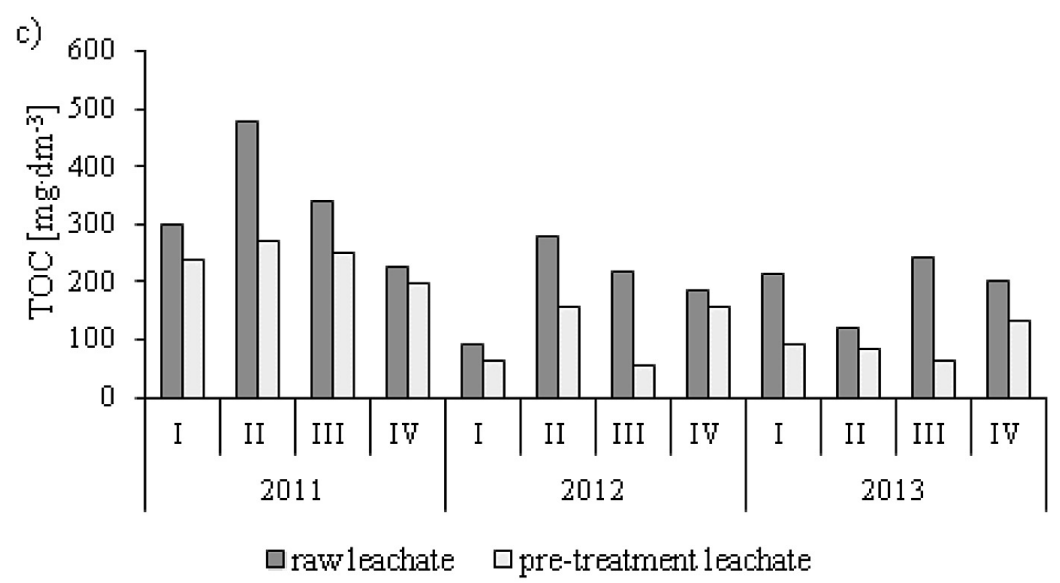

Figure 1. Mean quarterly concentrations of organic substances expressed as $\mathrm{COD}(\mathrm{a}), \mathrm{BOD}_{5}$ (b) and TOC

(c) in raw leachate (dark bars) and in pre-treated leachate (light bars)

\section{Removal of biogenic substances}

Concentrations of ammonia nitrogen in leachates from municipal waste landfills ranges widely from 100 to $5,500 \mathrm{mg} \cdot \mathrm{dm}^{-3}$, and the main factor influencing the annual value is the age of the waste landfill [Renou et al. 2008, Shalini et al. 2012]. For the tested leachates and the reviewed periods, ammonia nitrogen concentrations ranged

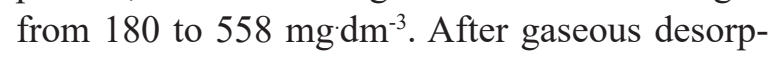

tion of ammonia from the leachates at $\mathrm{pH}>11$, the concentrations dropped just to $149-394 \mathrm{mg}$. $\mathrm{dm}^{-3}$ (Fig. 3), so the pre-treatment efficiency was from $5.7 \%$ up to the maximum $45 \%$.

The actual ammonia nitrogen concentrations exceeded the limits imposed by the Regulation for industrial effluents and for effluents discharged to sewers $\left(200 \mathrm{mg} \cdot \mathrm{dm}^{-3}\right.$ for effluents discharged for municipal liquid waste treatment plants with $P E \geq 5,000$ ). 


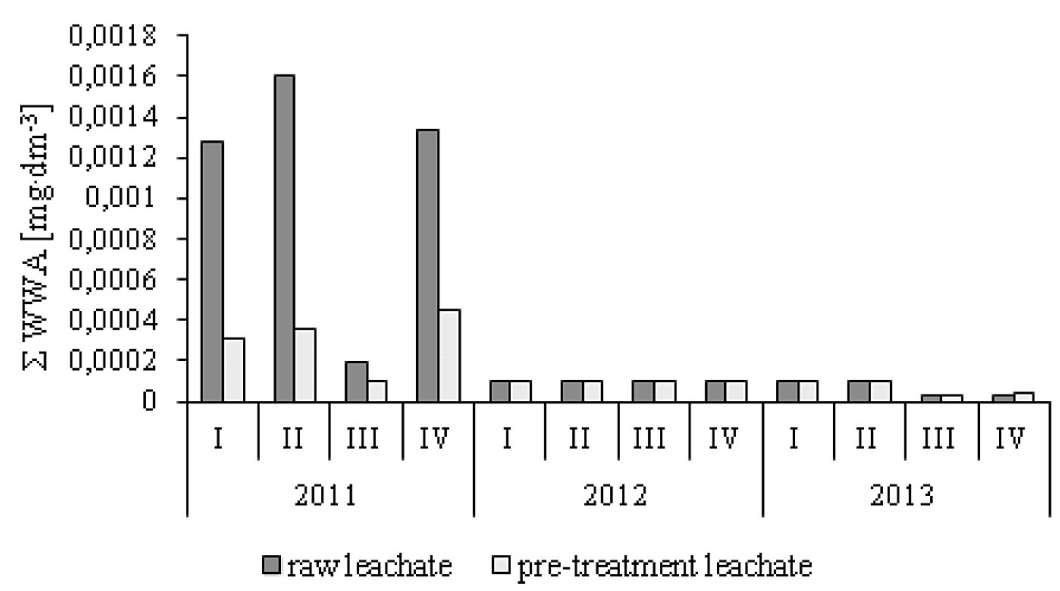

Figure 2. Mean quarterly concentrations of PAHs in raw leachate (dark bars) and in pre-treated leachate (light bars)

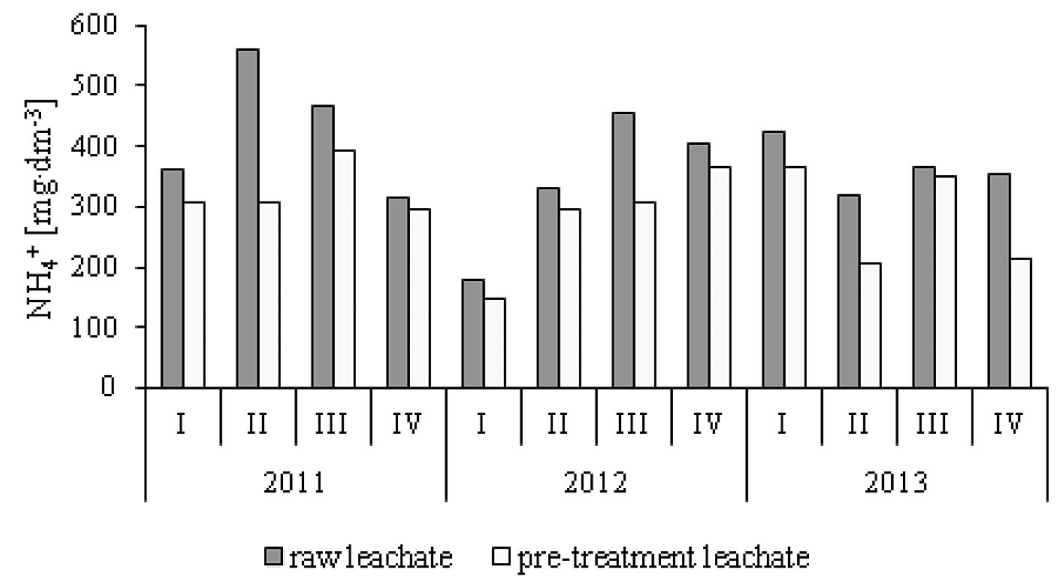

Figure 3. Mean quarterly concentrations of ammonia nitrogen in raw leachate (cark bars) and in pre-treated leachate (light bars)

Based on literature, the efficiency of ammonia recovery by gaseous desorption of at high $\mathrm{pH}$ can reach up to $95 \%$ [Kurniawan et al. 2006, Yuan et al. 2016] but there are many factors that can reduce it to a few or several percent [Blauvelt 2008].

The highest concentration of total phosphorus in raw leachate was recorded in the $2^{\text {nd }}$ quarter of $2011\left(4.34 \mathrm{mgdm}^{-3}\right)$ and the lowest on in the $1^{\text {st }}$ quarter of $2012\left(0.96 \mathrm{mg} \cdot \mathrm{dm}^{-3}\right)$. For pre-treated leachate, the top value was recorded in quarter 2 . $2012\left(3.17 \mathrm{mg} \cdot \mathrm{dm}^{-3}\right)$ and the lowest one in quarter 4. 2013 (0.28 mg.dm $\left.{ }^{-3}\right)$ (Fig. 4).

\section{Heavy metals}

The largest concentration of total chromium in raw leachate was recorded in quarter


2012-2013 (0.01 mg dm ${ }^{-3}$ or less). For pre-treated leachates, the corresponding values were $0.12 \mathrm{mg}$. $\mathrm{dm}^{-3}$ in quarter 3. 2011 and max. $0.01 \mathrm{mg} \cdot \mathrm{dm}^{-3}$ in 2012-2013. According to the Regulation by the Minister of Environment [Dz.U. 2006, nr 135, poz. $964], 1 \mathrm{mg} \cdot \mathrm{dm}^{-3}$ is the limit for total chromium.

Table 2 shows mean yearly concentrations of raw metals in raw and pre-treated leachate. The levels remained relatively constant throughout the study, lower than the limits imposed by the Regulation by the Minister of Environment.

Kwaśniewska et al. [2012] examined 22 municipal waste dumps in Silesia, operated for from 1 to 25 years. The concentrations of heavy metals were as follows: $\mathrm{Pb}-0.04-0.08 \mathrm{mg} \cdot \mathrm{dm}^{-3}, \mathrm{Ni}$ $-0.03-0.29 \mathrm{mg} \cdot \mathrm{dm}^{-3}, \mathrm{Cd}-0.005-0.007 \mathrm{mg} \cdot \mathrm{dm}^{-3}$, $\mathrm{Hg}-0.0003-0.0006 \mathrm{mg} \cdot \mathrm{dm}^{-3}$. Leachates from younger dumps with $\mathrm{pH}<6.5$ had higher heavy metal concentrations than maturing and stabilized landfills, where $\mathrm{pH}$ is typically larger than 7.5. This ensues from better metal solubility at lower $\mathrm{pH}$ values and from the washout of metals from waste to leachate. 


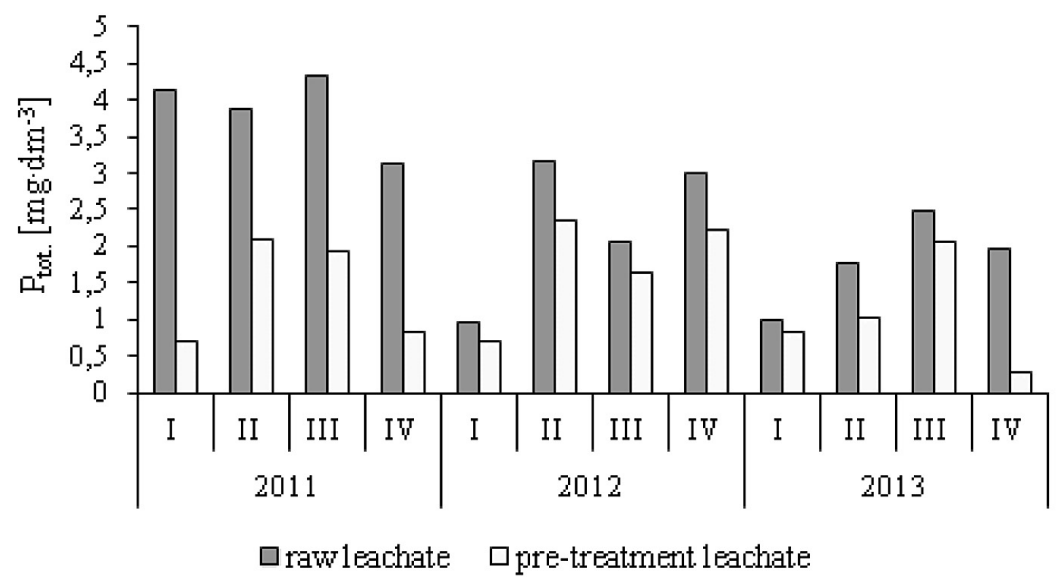

Figure 4. Mean quarterly concentrations of total phosphorus in raw leachate (cark bars) and in pre-treated leachate (light bars)

Table 2 Mean annual concentrations of heavy metals in the leachates compared to the daily limits for industrial effluents discharged to sewers imposed by the Regulation by the Minister of Environment

\begin{tabular}{|c|c|c|c|c|c|c|}
\hline \multirow{3}{*}{ Metal } & \multicolumn{6}{|c|}{ Year } \\
\hline & \multicolumn{2}{|c|}{2011} & \multicolumn{2}{|c|}{2012} & \multicolumn{2}{|c|}{2013} \\
\hline & 1. & 2. & 1. & 2. & 1. & 2. \\
\hline Lead $\left[\mathrm{mg} \mathrm{dm}^{-3}\right]$ & 0.1 & 0.1 & 0.11 & 0.04 & 0.3 & 0.3 \\
\hline Kadmium [mg $\left.\mathrm{dm}^{-3}\right]$ & 0.4 & 0.04 & 0.01 & 0.009 & 0.006 & 0.006 \\
\hline Copper $\left[\mathrm{mg} \cdot \mathrm{dm}^{-3}\right]$ & 0.02 & 0.02 & 0.02 & 0.01 & 0.04 & 0.03 \\
\hline Zink $\left[\mathrm{mg} \cdot \mathrm{dm}^{-3}\right]$ & 0.05 & 0.04 & 0.05 & 0.04 & 0.08 & 0.07 \\
\hline Chrome (VI) $\left[\mathrm{mg} \cdot \mathrm{dm}^{-3}\right]$ & 0.06 & 0.03 & 0.01 & 0.01 & 0.01 & 0.01 \\
\hline Mercury $\left[\mathrm{mg} \cdot \mathrm{dm}^{-3}\right]$ & 0.0003 & 0.0003 & 0.0005 & 0.0005 & 0.00093 & 0.0002 \\
\hline Nickel $\left[\mathrm{mg} \cdot \mathrm{dm}^{-3}\right]$ & 0.04 & 0.05 & 0.06 & 0.06 & 0.13 & 0.13 \\
\hline
\end{tabular}

1. raw leachate

2. pre-treatment leachate

\section{$\mathrm{pH}$ and electrolytic conductivity}

$\mathrm{pH}$ in the leachates ranged from 6.51 to 7.7 (Fig. 5). The gaseous desorption of ammonia requires a higher $\mathrm{pH}$ and after the process the product is neutralized, therefore $\mathrm{pH}$ of the pre-treated leachates ranged from 7.57 to 9 .

Measurements of specific conductivity are used mainly for estimation of the total content of substances dissolved in a solution. $\mathrm{pH}$ values of the leachates were first increased and then reduced. This resulted in precipitation of mineral compounds, so the values of electrolytic conductivity in the pre-treated leachates was reduced. The top values of electrolytic conductivity in the raw leachate, up to $8,900 \mu \mathrm{S} \cdot \mathrm{cm}^{-1}$, were observed in quarter 2. and in quarter 3. 2011 and the lowest in quarter 1. $2012\left(5081 \mu \mathrm{S} \cdot \mathrm{cm}^{-1}\right)$. Pretreatment of leachates with $\mathrm{pH}=11$ in aeration tanks reduced electrolytic conductivity by from 3,998 to $8,400 \mu \mathrm{S} \cdot \mathrm{cm}^{-1}$ (Fig. 6).

\section{CONCLUSIONS}

According to the study on the efficiency of leachate pre-treatment by gaseous desorption of ammonia, the efficiency of recovery of organic substances (COD), including biodegradable carbon compounds $\left(\mathrm{BOD}_{5}\right)$, during the period under review showed strong variation: from $7 \%$ to $44 \%$ and from $4 \%$ to $75 \%$, respectively. The resulting $\mathrm{BOD}_{5} / \mathrm{COD}$ ratio $(0.23: 0.54)$ and the reduction of toxic compounds (more than $45 \%$ of all the 16 PAHs removed, compliance with concentration limits for PAHs and heavy metals) were favorable. However, the efficiency of recovery of ammonia nitrogen ranged from just $5.7 \%$ to $45 \%$, so the method was inadequate from the point of view of its usual purpose.

The problem of wastes including waste storage products, such as leachates, affects the whole environment (air, soils, underground waters) and leads to a decline in biodiversity and aggravation 




Figure 5. Mean quarterly $\mathrm{pH}$ in raw leachate (cark bars) and in pre-treated leachate (light bars)

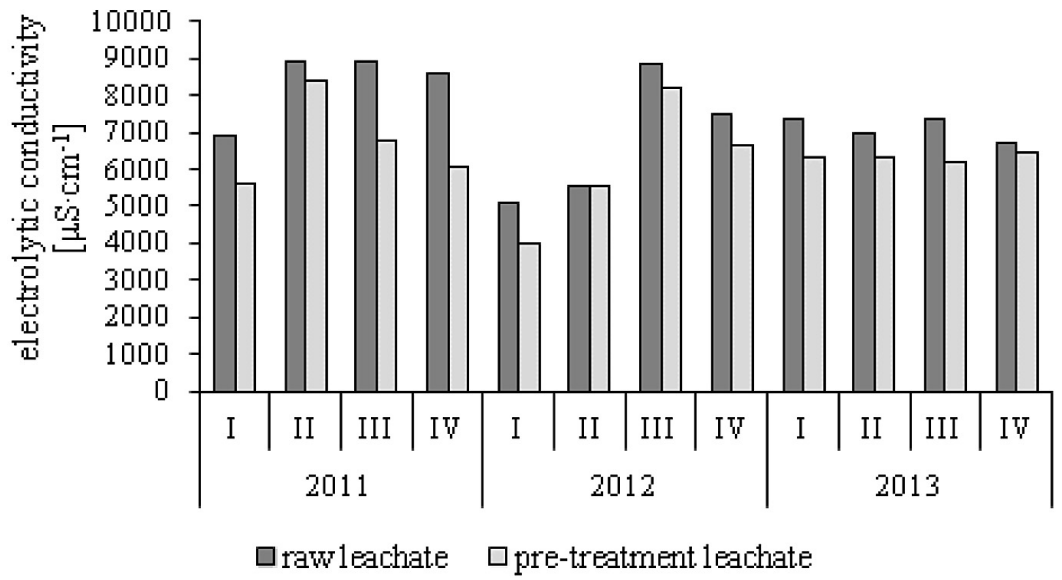

Figure 6. Mean quarterly electrolytic conductivity in raw leachate (cark bars) and in pre-treated leachate (light bars)

of human health. No efficient remedy has been yet found for all the mess accompanying economic growth. It has become a part of our lives and, as such, needs to be encompassed in a multidimensional responsible awareness of creation of a new reality. Therefore, the idea of retardation as a holistic approach to environmental problems by self-imposed control of one's existential needs seems to be one of the key solutions for the new century, also with respect to broadly defined waste management.

\section{REFERENCES}

1. Ahmed F.N., Lan C.Q. 2012. Treatment of landfill leachate using membrane bioreactors: A review. Desalination, 287, 41-54.

2. Blauvelt A. 2009. Removal of Ammonia From Landfill Leachate. A Major Qualifying Project submitted to the Faculty of Worcester Polytechnic In- stitute in partial fulfillment of the requirements for the Degree of Bachelor of Science.

3. Bonmati A., Flotats X. 2003. Air stripping of ammonia from pig slurry: characterisation and feasibility as a pre- or post-treatment to mesophilic anaerobic digestion. Waste Manage., 23, 261-272.

4. Calli B., Mertoglu B., Inanc B. 2005. Landfill leachate management in Istanbul: applications and alternatives. Chemosphere, 59, 819-829.

5. Cotman M., Gotvajn A.Z. 2010. Comparison of different physico-chemical methods for the removal of toxicants from landfill leachate. J. Hazard. Mater., 178, 298-305.

6. Foo K.Y., Hameed B.H. 2009. An overview of landfill leachate treatment via activated carbon adsorption process. J. Hazard. Mater., 171, 54-60.

7. Guo J.S., Abbas A.A., Chen Y.P., Liu Z.P., Fang F., Chen P. 2010. Treatment of landfill leachate using a combined stripping, Fenton, SBR, and coagulation process. J. Hazard. Mater., 178, 699-705.

8. Koc-Jurczyk J. 2014. Removal of Refractory Pol- 
lutants from Landfill Leachate Using Two-Phase System. Water Environ. Res., 86, 74-80.

9. Kostecka J. 2010. Retardacja przekształcania zasobów przyrodniczych jako element zrównoważonego rozwoju. In: Retardacja materialnego przekształcania zasobów przyrodniczych. Osiągnięcia, problemy, perspektywy. Kostecka J. (ed.), Biuletyn KPZK PAN, 242, 27-49.

10. Kostecka J. 2013. Retardacja tempa życia i przekształcania zasobów przyrody - wybrane implikacje obywatelskie. Inżynieria Ekologiczna, 34, 38-52.

11. Kostecka J., Kostecki A.W. 2014. Retardacja wykorzystywania i kreowania ekosystemów w terenie zurbanizowanym. Biuletyn KPZK PAN, 254, 85-112.

12. Kurniawan T.A., Lo W.-H i Chian G.Y.S. 2006. Degradation of recalcitrant compo-unds from stabilized landfill leachate using a combination of ozone-GAC adsorption treatment. J. Hazard. Mater., B137, 433-455.

13. Kwasniewska J., Nałęcz-Jawecki G., Skrzypczak A., Płaza G.A., Matejczyk M. 2012. An assessment of the genotoxic effects of landfill leachates Rusing bacterial and plant tests. Ecotox. Environ. Safe., 75, 55-62.

14. Liu Z.P., Wu W.H., Shi P., Guo J.S., Cheng J. 2015. Characterization of dissolved organic matter in landfill leachate during the combined treatment process of air stripping, Fenton, SBR and coagulation. Waste Manage., 41, 111-118.

15. Matejczyk, M., Płaza, G.A., Nałęcz-Jawecki, G., Ulfig, K., Markowska-Szczupak, A. 2011. Estimation of the environmental risk posed by landfills using chemical, microbiological and ecotoxicological testing of leachates. Chemosphere, 82, 1017-1023.

16. Renou S., Givaudan J.G., Poulain S., Dirassouyan F., Moulin P., 2008. Landfill leachate treatment: Review and opportunity. J. Hazard. Mater., 150, 468-491.

17. Slack R.J., Gronow J.R., Voulvoulis N. 2005. Household hazardous waste in municipal landfills: contaminants in leachate. Sci. Total Environ., 337, 119-137.

18. Wiszniowski J., Robert D., Surmacz-Górska J., Miksch K., Weber J.V. 2006. Landfill leachate treatment methods: A review. Enviromental Chemistry Letters, 4, 51-61.

19. Yuan Q., Jia H.J., Poveda M. 2016. Study on the effect of landfill leachate on nutrient removal from municipal wastewater. J. Environ. Sci., 43, $153-158$.
20. Rozporządzeniu Ministra Budownictwa $\mathrm{Z}$ dnia 14 lipca 2006 r. w sprawie sposobu realizacji obowiązków dostawców ścieków przemysłowych oraz warunków wprowadzania ścieków do urządzeń kanalizacyjnych (Dz. U. 2006, nr 135, poz. 964).

21. Rozporządzeniu Ministra Środowiska z dnia 26 lutego 2009 r. w sprawie szczegółowych wymagań dotyczących lokalizacji, budowy, eksploatacji i zamknięcia, jakim powinny odpowiadać poszczególne typy składowisk odpadów(Dz.U.39, poz. 320).

22. PN-ISO 5667-10:1997 Polska Norma: Jakość wody - Pobieranie próbek - Wytyczne pobierania próbek ścieków.

23. PN-EN 1899-2:2002 Polska Norma: Jakość wody - Oznaczanie biochemicznego zapotrzebowania tlenu po n dniach (BZTn) - Część 2: Metoda do próbek nierozcieńczonych.

24. PN-ISO 6060:2006 Polska Norma: Jakość wody - Oznaczanie chemicznego zapotrzebowania tlenu.

25. PN-EN 1484:1999 Polska Norma: Analiza wody - Wytyczne oznaczania ogólnego węgla organicznego (OWO) i rozpuszczonego węgla organicznego (RWO).

26. PN-ISO 17993:2005 Polska Norma: Jakość wody - Oznaczanie 15 wielopierścieniowych węglowodorów aromatycznych (WWA) w wodzie metodą HPLC z detekcją fluorescencyjną po ekstrakcji ciecz-ciecz.

27. PN-ISO 5664:2002), Polska Norma: Jakość wody - Oznaczanie azotu amonowego - Metoda destylacyjna z miareczkowaniem.

28. PN-EN 6878:2006) Polska Norma: Jakość wody - Oznaczanie fosforu - Metoda spektrometryczna z molibdenianem amonu.

29. PN-EN 1233:2000P Polska Norma: Jakość wody - Oznaczanie chromu -- Metody absorpcyjnej spektrometrii atomowej.

30. PN-ISO 8288:2002 Polska Norma: Jakość wody - Oznaczanie kobaltu, niklu, miedzi, cynku, kadmu i ołowiu -- Metody atomowej spektrometrii absorpcyjnej z atomizacją w płomieniu.

31. PN/90/C-04540.01 Polska Norma: Woda i ścieki - Badania pH, kwasowości i zasadowości - Oznaczanie pH wód i ścieków o przewodności elektrolitycznej właściwej $10 \mathrm{~ms} /$ cm i powyżej metodą elektrometryczną.

32. PN-EN 27888:1999 Polska Norma: Jakość wody - Oznaczanie przewodności elektrycznej właściwej. 